\title{
EVOLUTION AND AGE RELATIONS OF KARST LANDSCAPES
}

\section{RAZVOJ IN STAROSTNI ODNOSI KRAŠKIH POKRAJIN}

\author{
William B. WHITE ${ }^{1}$
}

\begin{abstract}
UDC 551.44

William B. White: Evolution and age relations of karst landscapes

Any karst landscape is a work in progress. The observed evolution of the landscape is dictated by competing rate processes of surface denudation, stream downcutting, cave development, and tectonic uplift. Quantitative data on these processes, applied to two physiographic provinces of the Appalachian Mountains of eastern United States gives ages and time scales that are in agreement with previous geomorphic interpretation. The results are anchored, very loosely, by the few dates that have been established for cave sediments. Unfortunately, the measured rates vary over an order of magnitude as a result of local circumstances making regional interpretation a rough approximation at best.

Key words: fluviokarst, karst denudation, landscape evolution.
\end{abstract}

Izvleček

UDK 551.44

William B. White: Razvoj in starostni odnosi kraških pokrajin

Vsaka kraška pokrajina je delo, ki napreduje. Razvoj pokrajine, ki ga je mogoče opazovati, je odvisen od medsebojno tekmujočih procesov površinske denudacije, vrezovanja površinskih tokov, razvoja jam in tektonskega dvigovanja. Številčni podatki o teh procesih, zbrani za dve fiziografski enoti v gorovju Apalači na vzhodu ZDA kažejo, da se starost in časovna skala ujemata $\mathrm{s}$ prejšnjimi geomorfnimi razlagami. Izsledke bolj ohlapno potrjuje nekaj podatkov, dobljenih za jamske sedimente. Žal pa so spremembe razmerja hitrosti zaradi lokalnih posebnosti v velikosti cele magnitude in je torej regionalna interpretacija $\mathrm{v}$ najboljšem primeru le grob približek.

Ključne besede: kraška denudacija, razvoj pokrajine.

\section{INTRODUCTION: WHAT DO WE MEAN BY THE “AGE” OF A KARST LANDSCAPE?}

By "landscape", we usually mean some defined area of the earth's surface as it exists at a single moment of time. Although most of the landforms remain constant on a human time scale, they are actually in the process of continuous evolution. In at least a microscopic way, today's landscape is not quite the same as yesterday's landscape. If the time scale is extended to thousands or millions of years, very large changes will have occurred to the landscape. Caves will have come and gone. A karst landscape, such as a doline plain, might superficially look the same but they wouldn't be the same dolines. The land surface is continuously lowered by dissolution. Old dolines disappear and new dolines are formed.
Thus when we speak of the "age" of a karst landscape we must carefully specify both spatial scales and time scales. At the largest scales we can talk about global chemical erosion over geologic time (Gibbs et al., 1999). We can talk about the general lowering of a karst landscape, the phenomenon generally called "karst denudation". We can talk about the differential dissolution that produces surface karst landforms. We can talk about subsurface dissolution that produces caves. We can talk about the relative rates of landscape evolution on karstic and non-karstic rocks. We can talk about rates of tectonic uplift that provide the gravitational gradients that drive all of the processes. The observed landscape in any geo-

${ }^{1}$ Materials Research Institute and Department of Geosciences, The Pennsylvania State University,University Park, PA 16802 USA; e-mail:wbw2@psu.edu

Received/Prejeto: 20.12.2006 
logic setting is the result of the interaction of all of these competing rate processes. As a result, "age" becomes a very slippery concept.

The objective of the present paper is to determine what constraints on the time evolution of karst landscapes can be extracted from known rates of the landscape processes. The discussion will be limited to fluviokarst. This means that consideration much be given to mass transport by surface streams on both carbonate and non-carbonate rocks as well as subsurface mass transport by dissolution. Illustrative examples are taken from the Appalachian Mountains of eastern United States. In the Appalachians are displayed two geologic settings: (1) The limestone valleys of the folded Appalachians where the karst surface is exposed across wide valley floors so that the disolutional dissection of the karst is primarily vertical and distributed across the surface. (2) The Appalachian Plateaus where the carbonate rocks are protected by clastic caprock and where the dissolutional attack is primarily by valley incision around the perimeter.

\section{UNIFORM LANDSCAPE LOWERING: KARST DENUDATION}

Setting aside the necessity for also removing insoluble residue, the evolution of a carbonate rock landscape can be considered to be a purely chemical process. The rock mass is taken into solution and carried away by the continuous flux of water that moves through the system. Any measure of the rate of carbonate removal can be recalculated as an average lowering of the karst surface, a quantity known as the karst denudation rate.

Various methods have been devised for the direct measurement of denudation rate (summarized by White, 2000). The rate of surface lowering can be measured directly on exposed rock surfaces using embedded reference pins and a precision micrometer (High and Hanna, 1970). The micrometer works best on bare rock surfaces. Most limestone dissolution takes place under a soil mantle. A technique to measure dissolution rates in soil is to bury carefully weighed plaques of limestone for a known time, then re-excavate and weigh them again (Gams, 1981).

On the scale of the entire drainage basin, it is possible to estimate denudation rate by a mass balance calculation using the volume of water leaving the basin and the concentration of dissolved carbonates contained in the water. The denudation rate is then given by

$$
D_{n}=\frac{1}{N_{L} A} \frac{K}{\rho t_{R}} \int_{t_{1}}^{t_{2}} Q(t) H(t) d t
$$

In this equation, $\mathrm{D}_{\mathrm{n}}$ is the denudation rate in $\mathrm{m}^{3} \mathrm{~km}^{-2} \mathrm{yr}^{-1}$ (numerically equivalent to the more common unit of $\mathrm{mm} / \mathrm{ka}$ ), $A$ is the basin area in $\mathrm{km}^{2}, \mathrm{~N}_{\mathrm{L}}$ is the fraction of the basin underlain by carbonate rocks, $\rho$ is the density of carbonate rock in $\mathrm{gcm}^{-3}, \mathrm{t}_{\mathrm{R}}$ is the period of record in years, $\mathrm{Q}(\mathrm{t})$ is the instantaneous discharge in $\mathrm{m}^{3} \mathrm{~s}^{-1}$ (i.e. the hydrograph) and $\mathrm{H}(\mathrm{t})$ is the instantaneous $(\mathrm{Ca}+\mathrm{Mg})$ hardness in $\mathrm{gcm}^{-3}$ (i.e. the chemograph). The constant, $\mathrm{K}$, contains unit conversions and has the value
$10^{-12}$ for the units given. Because the mass balance equation requires continuous records of both discharge and hardness which are not often available, a variety of approximations have been proposed.

If the reaction between infiltrating water and carbonate rock at the base of the epikarst is assumed to reach equilibrium, the denudation rate can be calculated from first principles (White, 1984).

$$
D_{n}=\frac{M_{c a l}}{\rho \sqrt[3]{4}}\left(\frac{K_{c} K_{1} K_{\mathrm{CO}_{2}}}{K_{2} \gamma_{\mathrm{Ca}^{2+}} \gamma^{2} \mathrm{HCO}_{3}}\right)^{\frac{1}{3}} P_{\mathrm{CO}_{2}}^{\frac{1}{3}}(P-E)
$$

In this equation, $D_{n}$ is the denudation rate in $\mathrm{mm} /$ $\mathrm{ka}$. Mcal is the molecular weight of calcite (or a weighted mix of the molecular weights of calcite and dolomite) and $\rho$ is the rock density in $\mathrm{gcm}^{-3}$. The K's are the usual equilibrium constants for carbonate reactions and the $\gamma$ 's are the activity coefficients. P-E (precipitation minus evapotranspiration) is the annual runoff in $\mathrm{mm} / \mathrm{yr}$

Many of the earlier measurements of karst denudation rates were reviewed and analyzed by Smith and Atkinson (1976). A selection of more recent data are displayed in Figure 1. The chosen examples include data from each of the three measurement methods described above and these give comparable results. The regional environments represented in Figure 1 include arid, alpine, northern, and temperate. Denudation rates vary by a factor of 5-10 within each group but the groups are almost completely overlapping. Local conditions at the sampling site, including soil cover, available water, and rock lithology, all contribute so that local site variation masks regional scale variations. There is also the question of how denudation rates have changed in response to climatic fluctuations of the Pleistocene. For the regional scale landscape evolution of interest in this paper, 


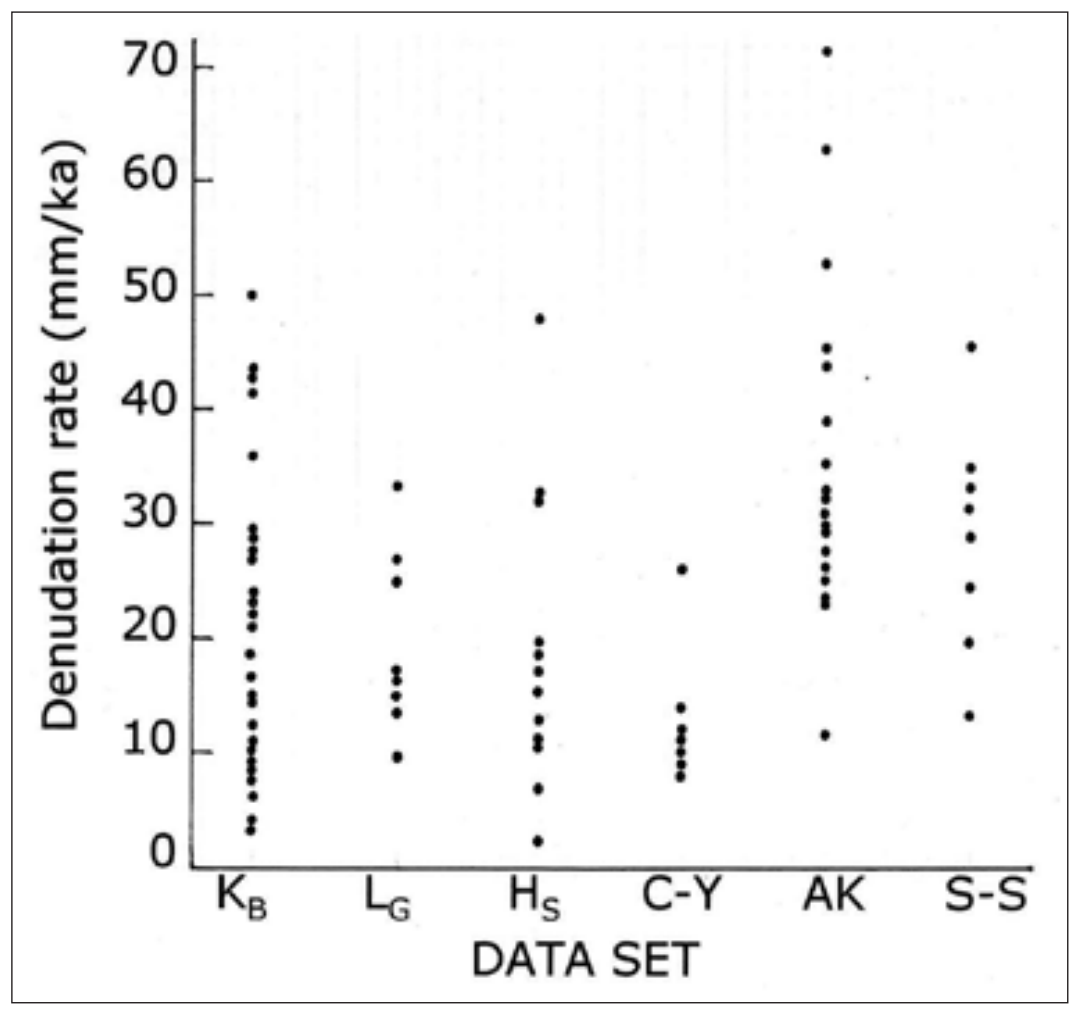

about the best that can be said is that exposed karst surfaces in the Appalachian Mountains would be lowered by dissolution at a rate of $20-30 \mathrm{~mm} / \mathrm{ka}$.
Fig. 1: Measured denudation rates. All data have been converted to units of $\mathrm{mm} /$ ka. $K_{R}-M t$. Kräuterin, Austria (buried tablets) (Zhang et al., 1995). $L_{G}-$ Logatec Doline, Slovenia (buried tablets) (Gams, 1981).

$H_{s}$ - Hochschwab Massif, Austrian Alps (buried tablets) (Plan, 2005).

$C-Y$ - Cooleman Plain and Yarrangobilly Caves area, New South Wales, Australia (microerosion meter) (Smith et al., 1995). AK-southeastern Alaska (microerosion meter) (Allred, 2004). S-S - SaltfielletSvartisen area, northern Norway (mass balance) (Lauritzen, 1984).

\section{RATES OF VALLEY DEEPENING}

Regional rivers draining through areas of fluviokarst cut normal valleys in the clastic rocks that overlie, underlie, or border the karstic rocks and may appear as surface streams in valleys cut into the karstic rocks. Measurements of the downcutting rates of larger rivers are difficult because many of them, in their lower reaches, are at grade with a sediment load balanced against the discharge. Lowering of the bedrock channel can be very slow. A few data are given in Table 1. Lowering rates in the tectonically stable Appalachians fall in the same 20$30 \mathrm{~mm} / \mathrm{ka}$ range as is found for denudation of karst surfaces. Only one example, the Bighorn Basin in western United States is a factor of ten higher and may represent a higher rate of tectonic uplift.
Small tributary streams that flow from surrounding non-karstic lands onto the karst and then sink at the contact with the soluble rocks seem to have a much higher rate of channel lowering. Some direct micrometer measurements in the beds of sinking streams are given in Table 2. Sinking stream waters are generally highly unsaturated so that sinking streams downcut rapidly into the carbonate rock at their sink points. Similar measurements at spring outlets produce much smaller numbers. The highest values yet reported were for a muskeg-draining stream in Alaska (Allred, 2004) where there is an implication that organic acids may also play a role.

Tab. 1. Downcutting Rate of Some Moderate-Size Rivers

\begin{tabular}{lcl}
\hline Name and Location & Rate $(\mathrm{mm} / \mathrm{ka})$ & Reference \\
\hline Bighorn River, Wyoming & 350 & Stock et al. (2006) \\
East Fork, Obey River, Tennessee & 30 & Sasowsky et al. (1995) \\
& & Anthony \& Granger (2004) \\
Green River at Mammoth Cave, Kentucky & 30 & Granger et al. (2001) \\
Juniata River, Newport, Pennsylvania & 27 & Sevon (1989) \\
New River at Pearisburg, Virginia & 27 & Granger et al. (1997) \\
\hline
\end{tabular}


Tab. 2. Downcutting Rate in Small Karst Streams

\begin{tabular}{lcl}
\hline Name and Location & Rate $(\mathrm{mm} / \mathrm{ka})$ & Reference \\
\hline Cataract Cave, southeast Alaska & 137 & Allred (2004) \\
County Clare, Ireland & 500 & High and Hanna (1970) \\
& 400 & \\
Muskeg Inflow Cave, southeast Alaska & 1670 & Allred (2004)) \\
Slate Cave, southeast Alaska & 1080 & Allred (2004) \\
Yarrangobilly, NSW, Australia & 180 & Smith et al. (1995) \\
\hline
\end{tabular}

\section{CAVE DEVELOPMENT IN FLUVIOKARST}

Caves - here considered to be master trunk caves related to surface base-level streams - have a three-stage development. (1) The initiation phase is the evolution of an initial mechanical fracture to a critical-size protoconduit about one centimeter in aperture. (2) The enlargement phase takes the protoconduit up to the meters to tens of meters diameter of a typical cave passage. (3) The stagnation and decay phase is that period after the cave passage has been drained and abandoned by lowering base levels. As the stagnation phase progresses, entrances are developed and process of collapse, speleothem growth, and sediment in- filling choke off the once continuous conduit. Deepening of surface valleys breaks the cave into fragments.

The initiation phase is almost purely chemical. Nearly saturated water percolates along alternative paths in the carbonate rock, slowly enlarging them. The initiation phase ends when one pathway becomes sufficiently large to permit critically undersaturated water to pass completely through the aquifer. As a result, the final layout of the conduit system is largely determined during the initiation phase. The initiation phase is particularly amenable to geochemical modeling and some very elegant models have been constructed (Dreybrodt et al., 2005). The time scale for the initiation depends on assumed initial conditions but appears to be in the range of 10,000 to 20,000 years.

The enlargement phase is largely independent of outside factors. The rate of retreat of passage walls can be described by the PalmerDreybrodt equation (Palmer, 1991).

$$
S=\frac{31.56 k\left(1-\frac{C}{C_{S}}\right)^{n}}{\rho_{R}}
$$

$S$ is the rate of wall retreat in $\mathrm{cm} / \mathrm{yr}$. Some calculations for passage

Fig. 2: Enlargement phase for typical conduits assuming various carbon dioxide partial pressures based on the Palmer-Dreybrodt equation. 
enlargement are plotted in Fig. 2. The rate constant, k, was taken from Palmer (1991). The rock density, $\rho_{\mathrm{R}}$ was set equal to $2.65 \mathrm{~g} / \mathrm{cm}^{3}$. The reaction order, $\mathrm{n}=1$, in the fast dissolution regime. The only environmentally sensitive parameter is the saturation concentration of calcium carbonate which depends on the carbon dioxide partial pressure. Figure 2 shows the passage enlargement rates expected for a reasonable range of $\mathrm{CO}_{2}$ pressures. Although the details are site-specific, even rough calculations suggest that 50,000 to 100,000 years are sufficient to allow a master cave to develop.

The relationship between hydraulic gradient, $h_{f} / L$, discharge, $\mathrm{Q}$, and passage radius, $\mathrm{R}$, is given by a form of the Darcy-Weisbach equation

$$
\frac{h_{f}}{L}=\frac{f Q^{2}}{4 \pi^{2} g R^{5}}
$$

Some maximum gradients that can be supported by a given size conduit are plotted in Figure 3 for a selection of discharges.

Because of the low hydraulic resistance of conduit systems, the elevation difference between the headwaters and the downstream reaches of surface streams can provide sufficient head to drive the cave-forming process. By this process of autopiracy, caves develop beneath surface valleys (or more often in the valley walls) and drain off the flow from the surface stream. Such caves generally have flatter gradients than the valleys that they underdrain.

Unlike karst surfaces or surface valleys which are continuously evolving, caves remain as fixed elevation markers and are the only features of the karst landscape for which the age is locked in. Caves may ride upward with tectonic uplift, but otherwise remain fixed as the surface landscape falls around them. This is the stagna-

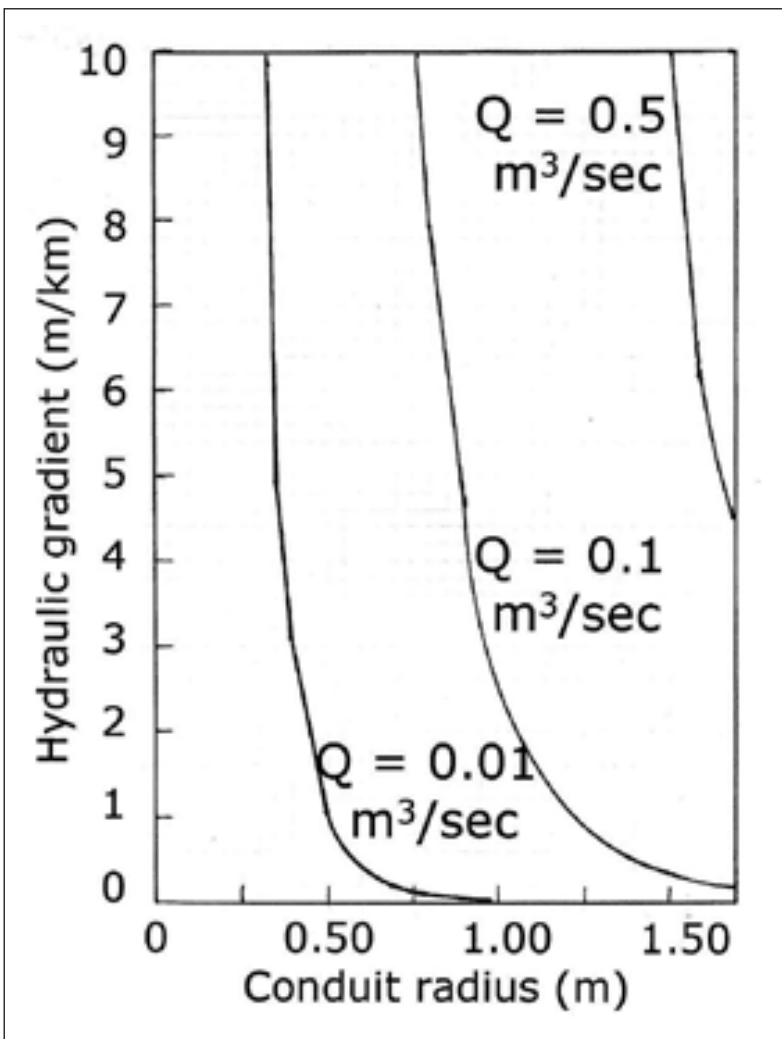

Fig. 3: Supportable hydraulic head as a function of conduit radius for various discharges. The Darcy-Weisbach friction factor, $f=100$. The gravitational acceleration, $g=9.8 \mathrm{msec}^{-1}$.

tion and decay phase in the cave's history and is the phase in which entrances are developed and the once-continuous conduit is fragmented as the surface lowers and valleys deepen. In terms of importance as biological habitat, the final stage is very important. Unfortunately, the details of the conduit decay of the conduit depends on local circumstances does not lend itself to numerical analysis.

\section{AGE RELATIONSHIPS IN THE PLATEAU FLUVIOKARST SETTING}

The Cumberland Plateau is the southern-most extension of the great Appalachian plateaus that extend from New York State into Alabama. The Cumberland Plateau in Tennessee and Alabama is an upland of low-dip Mississippian rocks. The plateau is capped with a highly resistant quartzite which provides a reference elevation at about 550 to 600 meters. The denudation of the resistant quartzite is very slow, $3-5 \mathrm{~mm} / \mathrm{ka}$, according to Anthony and Granger (2004). The plateau is bounded by a pronounced escarpment into which deep valleys (known locally as "coves") have been incised. At the base of the western escarpment is a karst surface known as the Highland Rim. The doline surface of the Highland Rim extends into many of the deeper coves. Mississippian limestones underlie the valley walls of the coves and much of the Highland Rim (Fig. 4).

The downcutting rate of one incised valley, that of the East Fork of the Obey River in north-central Tennessee was first calculated from magnetic reversals in the sediments of one of the caves in the valley wall (Sasowsky et al., 1995). This number was revised when cosmogenic isotope dating of the same cave showed that 


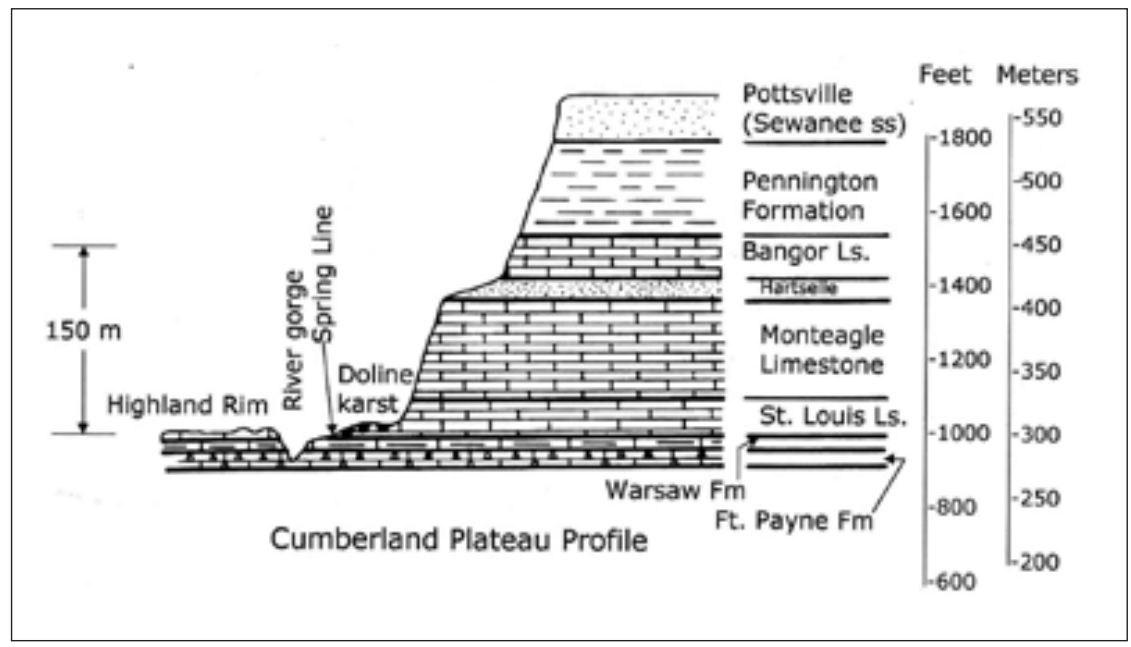

Fig. 4: Schematic cross-section through the western escarpment of the Cumberland Plateau. Thicknesses of individual beds are nominal values; bed thicknesses vary considerably over short distances (Milici et al., 1979).

the paleomagnetic measurements referred to an earlier reversal (Anthony and Ganger, 2004). The revised value of $30 \mathrm{~mm} / \mathrm{ka}$ (Table 1) is similar the downcutting rate of other moderate size rivers and also very similar to the expected denudation rate.

The Highland Rim surface at the base of the western escarpment has nearly eroded to the bottom of the carbonate sequence. It all about 150 meters of limestone have been removed. If the Highland Rim is raised according to the $30 \mathrm{~mm} / \mathrm{ka}$ denudation rate, approximately 5 million years ago, the erosion surface was at the top of the limestone. The sediments in Big Bone Cave were dated at 5.7 Ma (Anthony and Granger, 2004) and it was claimed that this date represents a time when the Cumberland River was flowing at the elevation of the Highland Rim.

\section{AGE RELATIONSHIPS IN APPALACHIAN VALLEY FLUVIOKARST SETTING}

The karst surfaces of the Great Valley and Valley and Ridge Provinces of the folded Appalachians are breached

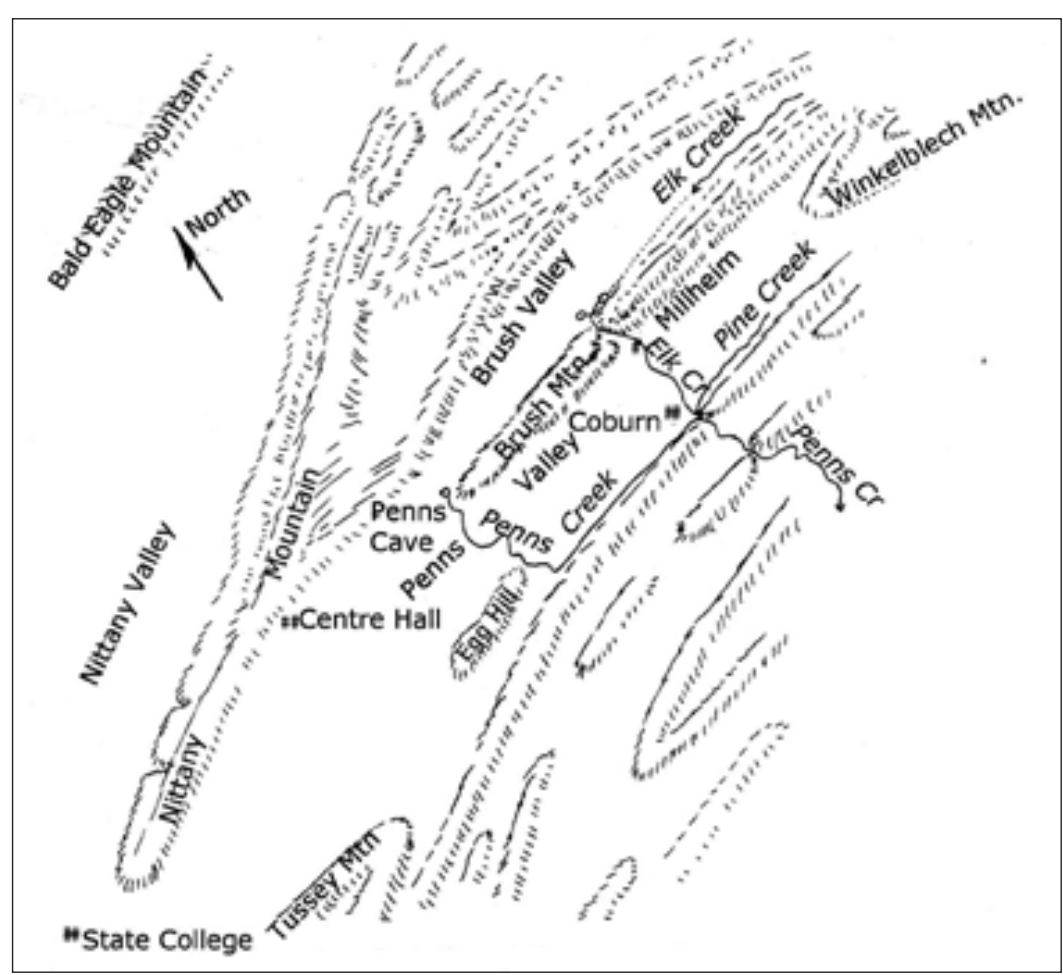

anticlines. Deep erosion along the anticlines has exposed the Ordovician and Cambrian limestones and dolomites which now form the valley floors. The more resistant quartzites on the flanks of the anticlines remain as long nearlyparallel ridges bounding the valleys (Fig. 5). Contemporary surface streams have downcut 50 to 75 meters into the valley surface. There must have been a time when the anticlines were first breached to expose the carbonate rocks to denudation. Figure 6 shows the sequence of events (without time scale) and includes the recognized erosion surfaces identified in central Pennsylvania.

The Nittany Valley near State College, Pennsylvania is an interfluve area. Here are found residual soils

Fig. 5: Sketch showing topographic relations in central Pennsylvania. Ridges are supported by resistant quartzite; most of the valley floors are underlain by Cambrian and Ordovician carbonate rocks. After Deike (1961). 


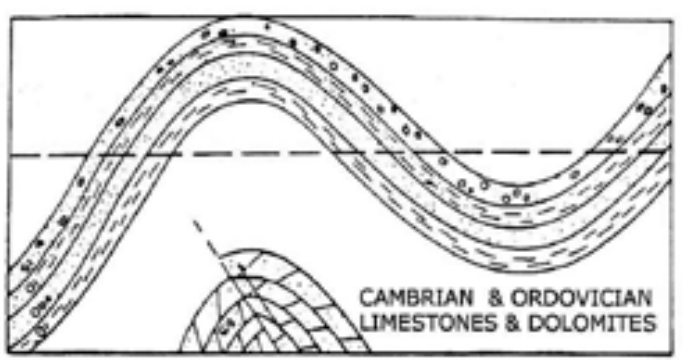

Schooley Peneplain
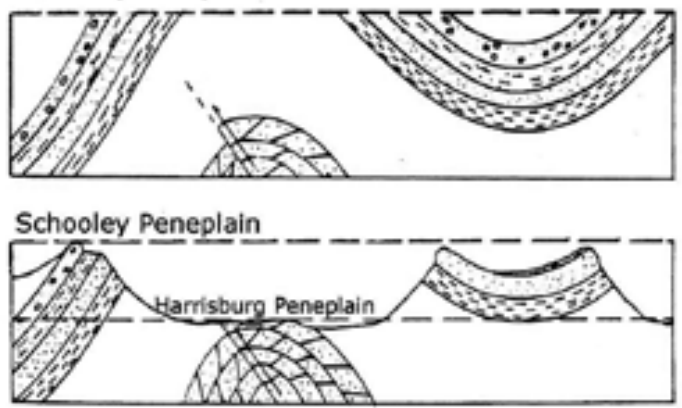

Schooley Peneplain

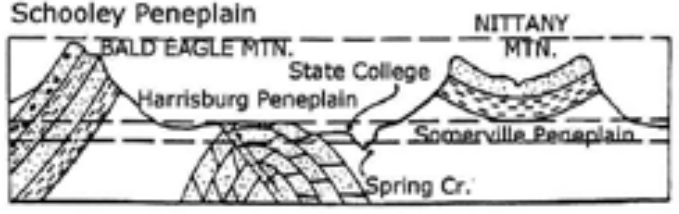

Fig. 6: The evolution of the Nittany Valley in central

Pennsylvania showing traditional erosion surfaces. After Gardner (1980).

with thicknesses averaging 50 meters. On the assumption that these are let-down soils consisting of the insoluble residues from the dissolution of the carbonate rocks, a calculation based on insoluble residue content and bulk density suggests that more than 425 meters of carbonate rock were removed to accumulate this thickness of soil (White and White, 1991). On the (quite possibly unreasonable) assumption that the denudation rate has been $30 \mathrm{~mm} / \mathrm{ka}$, the removal of 425 meters of carbonates would require on the order of 14 million years, placing the beginning of what has been a uniform denudation process in mid-Miocene time. The present relief between the valley floor and the ridge tops is about 250 meters. The carbonate surface at the beginning of the denudation process would be 175 meters above the present-day ridge tops. However, the estimated denudation would not include the entire carbonate section so it does not represent the breaching of the anticline which must have taken place earlier.

The accordant ridge-lines of the folded Appalachians are often taken to represent the Schooley Peneplain. If these quartzite-topped ridges erode as slowly as similar rocks on the Cumberland Plateau, the limestone would have filled the valley to the level of the ridge tops only 8 - $9 \mathrm{Ma}$ ago. The age of the Schooley Peneplain would be much less than many ages that have been assigned to it, some setting the age as far back as the Jurassic.

The valley floors which represent the Harrisburg Survey have been dissected by present day streams to produce an internal relief of about 60 meters. The caves of the Valley and Ridge Province are found within this interval. Some are inlet caves with high gradients due to the rapid downcutting of sinking streams. Others are fragments of base-level conduits. Given the observed rates of stream downcutting, the time span available for the development of these caves is $2-3$ million years.

\section{CONCLUSIONS}

Although doline plains give the impression of stable erosion surfaces, denudation measurements suggest the rate of lowering is comparable to the rate of downcutting of surface valleys. The horizontal surface is maintained because of the internal drainage through the dolines. It is, therefore, problematic to attempt to assign and age to karst surfaces.

Cave development is very rapid compared with the evolution of the surface landscape. Caves in tectonically stable areas serve as better markers of temporarily stable pauses in base level lowering than do either surface streams or the elevations of karst "erosion surfaces". This conclusion has been suspected at least since the work of Davies (1960) but was given much stronger support by recent cosmogenic isotope dating (Granger et al., 1963; Anthony and Granger, 1964). It is also supported by the present geochemical calculations and mass balance arguments. 


\section{REFERENCES}

Allred, K., 2004: Some carbonate erosion rates of southeast Alaska - Journal of Cave and Karst Studies 66, 89-97.

Anthony, D.M. \& D.E. Granger, 2004: A late Tertiary origin for multilevel caves along the western escarpment of the Cumberland Plateau, Tennessee and Kentucky, established by cosmogenic ${ }^{26} \mathrm{Al}$ and ${ }^{10} \mathrm{Be}$ - Journal of Cave and Karst Studies 66, 46-55.

Davies, W.E., 1960: Origin of caves in folded limestone - National Speleological Society Bulletin 22, 5-18.

Deike, R.G., 1961: Karst development in Brush Valley, PA - Nittany Grotto Newsletter 9, 121-128.

Dreybrodt, W., F. Gabrovšek \& D. Romanov, 2005: Processes of speleogenesis: A modeling approach - Carsologica, No. 4, 375 p.

Gams, I., 1981: Comparative research of limestone solution by means of standard tablets $-8^{\text {th }}$ International Congress of Speleology Proceedings, Bowling Green, Kentucky, USA, p. 273-275.

Gardner, T., 1980: Geomorphology of Nittany Valley - Chapter 5 in Soils and Geology of Nittany Valley, E.J. Ciolkosz, R.R. Parizek, G. W. Petersen, R.L. Cunningham, T.W. Gardner, J.W. Hatch, \& R.D. Shipman, Eds., The Pennsylvania State University Agronomy Series No. 64, p. 52-75, University Park, PA.

Gibbs, M.T., G.J.S. Bluth, P.J. Fawcett, \& L.R. Kump, 1999: Global chemical erosion over the last $250 \mathrm{MY}$ : Variations due to changes in paleogeography, paleoclimate, and paleogeology - American Journal of Science 299, 811-51.

Granger, D.E., D. Fabel \& A.N. Palmer, 2001: Pliocene - Pleistocene incision of the Green River, Kentucky, determined from radioactive decay of cosmogenic ${ }^{26} \mathrm{Al}$ and ${ }^{10} \mathrm{Be}$ in Mammoth Cave Sediments - Geological Society of America Bulletin 113, 825-836.

Granger, D.E., J.W. Kirchner \& R.C. Finkel, 1997: Quaternary downcutting rate of the New River, Virginia, measured from differential dcay of cosmogenic ${ }^{26} \mathrm{Al}$ and ${ }^{10} \mathrm{Be}$ in cave-deposited alluvium - Geology 25, 107-110.

High, D. \& F.K. Hanna, 1970:A method for the direct measurement of erosion on rock surfaces - British Geomorpological Research Group Technical Bulletin No. 5, p. 24.

Lauritzen, S.-E., 1984: Some estimates of denudation rates in karstic areas of the Saltfjellet - Svartisen Region, North Norway - Catena 11, 97-104.
Milici, R.C., G. Briggs, L.M. Knox, P.D. Sitterly \& A.T. Statler, 1979: The Mississippian and Pennsylvanian (Carboniferous) Systems in the United States - Tennessee - U.S. Geological Survey Professional Paper 1110-G, 38 p.

Palmer, A.N., 1991: Origin and morphology of limestone caves - Geological Society of America Bulletin 103, $1-21$.

Plan, L., 2005: Factors controlling carbonate dissolution rates quantified in a field test in the Austrian Alps - Geomorphology 68, 201-212.

Sasowsky, I.D., W.B. White \& V.A. Schmidt, 1995: Determination of stream-incision rate in the Appalachian plateaus by using cave-sediment magnetostratigraphy - Geology 23, 415-418.

Sevon, W.D., 1989: Erosion in the Juniata River drainage basin, Pennsylvania - Geomorphology 2, 303-318.

Smith, D.I. \& T.C. Atkinson, 1976: Process, landforms and climate in limestone regions - Chapter 13 in Geomorphology and Climate, E. Derbyshire, Ed., John Wiley, p. 367-409, London.

Smith, D.I., M.A. Greenaway, C. Moses, \& A.P. Spate, 1995: Limestone weathering in eastern Australia. Part I. Erosion rates - Earth Surface Processes and Landforms 20, 451-463.

Stock, G.M., C.A. Riihimaki, \& R.S. Anderson, 2006: Age constraints on cave development and landscape evolution in the Bighorn Basin of Wyoming, USA - Journal of Cave and Karst Studies 68, 76-84.

White, W.B., 1984: Rate processes: chemical kinetics and karst landform development - in Groundwater as a Geomorphic Agent, R.G. LaFleur, Ed., Allen \& Unwin, p. 227-248, London.

White, W.B., 2000: Dissolution of limestone from field observations - in Speleogenesis, A. Klimchouk, D.C. Ford, A.N. Palmer \& W. Dreybrodt, Eds., National Speleological Society, p. 149-155, Huntsville, AL.

White, W.B. and E.L. White, 1991: Karst erosion surface in the Appalachian Highlands - in Appalachian Karst, E.H. Kastning and K.M. Kastning, Eds. National Speleological Society, p. 1-10, Huntsville, AL.

Zhang, D., H. Fischer, B. Bauer, R. Pavuza \& K. Mais, 1995: Field tests of limestone dissolution rates in karstic Mt. Kräuterin, Austria - Cave and Karst Science 21, 101-104. 